Planning Theory \& Practice

\title{
Edward Soja: geographical imaginations from the margins to the core
}

\section{Margarida Queirós}

To cite this article: Margarida Queirós (2016) Edward Soja: geographical imaginations from the margins to the core , Planning Theory \& Practice, 17:1, 154-160, DOI: 10.1080/14649357.2015.1130447

To link to this article: https://doi.org/10.1080/14649357.2015.1130447

曲 Published online: 04 Mar 2016.

Submit your article to this journal $\pi$

Џll Article views: 348

View Crossmark data \lceil 


\section{Edward Soja: geographical imaginations from the margins to the core}

Very sadly after a long battle with illness, Professor Edward Soja passed away in Los Angeles in November, 2015 whilst this article was in production. The interview reported here took place in June 2013. We publish it as a tribute to Soja's life and the continued vitality of his work.

Margarida Queirós

Instituto de Geografia e Ordenamento do Território, Universidade de Lisboa and Centro de Estudos Geográficos, Universidade de Lisboa, Lisboa, Portugal

Before his sad and untimely death in November 2015, Edward Soja was one of the leading urban theorists in the world. His inspired trilogy on the "postmetropolitan transition" in urban studies, which influenced a generation of geographers and others all over the world, documents a brilliant career. Postmodern Geographies (Verso, 1989), Thirdspace (Blackwell, 1996b) and Postmetropolis (Wiley-Blackwell, 2000) ${ }^{1}$ opened a debate on the expansion of the interpretative power of spatiality, raising key issues that profoundly affect the discipline of geography. Moreover, through Soja, "spatial thinking" has reached beyond the disciplinary boundary of geography, and his work has been recognized by many disciplines outside geography - urbanism, architecture, design and so on. If, as he argued, "Explanation in geography is fine; explanation by geography is something else (Soja, 2011, p. 453), one of his most important legacies is the creation of a wider audience for new ideas involving urban geography, providing "intellectual leadership in the spatializing of the social sciences and humanities" (Soja, 2011, p. 453).

At 10 am on the 6th of June 2013, in a relaxed atmosphere at the Luskin Public Affairs building, UCLA, Professor Soja was starting his morning. While answering my questions, he often expanded on them, frequently anticipated the course of our talk and offered many unique insights. Some words he used a long time ago in a speech during a Symposium at the Stanford Law School came to me: "when faced with a strict binary choice, with an either/or option, one should reject the imposed binary, deconstruct and disorder it, and force it open to a multiplicity of alternative choices" Soja (1996a, p. 1421). Our discussion topics were certainly far removed from the "binaries" that have defined mainstream science for almost 200 years and soon the critical human geographer (or the post-modernist scholar?) surfaced with his trademark critical thought stressing the power of space, and giving geography an importance equivalent to history and sociology.

This paper aims to encapsulate our conversation and the subsequent interaction we had about his work; exploring how and why it matters to planners and geographers. I posit that the talk we had - the main topics I share here - bring a breath of fresh air to the work of those who contribute to theories and concepts of geography and planning and suggests ways in which we might develop further reflections of our own. So I hope to bring up the 'space' issue (again) as a stimulus to focus on the spatiality of society and on the way social relations are intertwined with space across time. I also want to highlight how the context in which we develop our work and live can be a major influence 
that enables (or constrains) the development of new insights. But the ultimate goal of this piece is specifically to encourage geographers and urban planners to "set aside their old taboos and reservations and enthusiastically engage in these new developments not just as followers but also as intellectual leaders." (Soja, 2011, p. 454)

\section{A spatial turn at the University of California Los Angeles}

In 1972 John Friedmann invited Soja to come to the Department of Urban Planning at UCLA. It turned out that at UCLA he would become more theoretical in his approach, in some ways even more theoretical than Friedmann, so the move marked a major turning point in his life. Soja considered that his work was profoundly shaped by the fact that he had shifted into an urban planning department: "If I'd stayed in a geography department I would have no discipline on my theoretical thinking; I could have been as abstract and irrelevant as I wished."2

At UCLA he very quickly understood that the students in the urban planning department were very progressive. They were willing to accept his theoretical ramblings as long as he spent some time talking about how they could be applied in a political planning context. At first glance it would look like a constraint, but after a while, Soja thought to himself: "I'm in a planning program, I've got to do something more directly relevant to planning." And so he started to focus a little on thinking about the usefulness of what he was doing, and that really sharpened his theoretical outlook, making him less abstract and, he believed, enabling his work to have a bigger impact.

A big influence on his thinking was Henri Lefebvre's La production de l'espace (Lefebvre, 1974). Soja read this book and was stunned because he had had similar thoughts about the importance of space. A Greek student, Costis Hadjimichalis, knew Lefebvre's work very well and helped Soja make sense of what he was reading. At that time he thought he was alone with nobody else thinking in that direction, and so Lefebvre's work was illuminating, and may have given him his "eureka moment" - "that was really a very exciting moment and really gave me tremendous confidence that the kinds of writings that I was doing and thinking about was, maybe, worthwhile following up".

One interesting fact is that Soja did not publish very much during the 1970s: only a very few articles up until 1980. It was when he published the "Socio-spatial Dialectic" (Soja, 1980). In addition to arguing that spatial relations were just as important as social relations in the development of capitalism, Soja's major message was that space is not a scientific object removed from ideology and politics; it has always been political and strategic. It is a product filled with ideologies). Then a new phase began. His thinking on the political and strategic subject of space was also a critique of Marxism itself. At that time, Soja considered himself a Marxist geographer but was amazed that other Marxist geographers forgot space: "They weren't doing very much on space and if they did deal with space it was just as a background, you know, very conventional rather than innovative."

With this paper Soja argued that capitalism shaped space. He also argued that feminists were claiming that patriarchy shaped space and that for African-Americans, racism shaped space. All of this was correct, but through his work, Soja was interested in how space could, in return, affect racism, class, or gender issues. For Soja, these relationships were being almost totally neglected. So this was at the heart of the "Socio-spatial Dialectic": - daring to say that the social and the spatial are of equal importance.

Soja did not think that there is or ever was an "LA School" but, given his 30 years of thinking and writing about the spatial turn and working with many doctoral students, can we say that there is a "Soja School"? In Soja's opinion there are a large group of his students at UCLA Urban Planning who have one of several things in common. Before working with Soja, they started out in areas unrelated to geography, but are now making their careers in geography. There must be around eight or ten that have changed 
fields having worked with him and then gone on to pursue jobs in geography - Mustafa Dikec, Olivier Kramsch, Sue Ruddick and Miguel Kanai, and one of his first PhD students, Costis Hadjimichalis, are just some he remembered off hand. They do not necessarily do work which follows his ideas directly, as they have developed their own approaches, yet they always recognize the presence of Soja's ideas as they branch off in new directions. As a scholar, Soja thought that if he had stayed in a geography department he would not have become the geographer he evolved into. He always felt he was outside mainstream geography and this was not always very comfortable: "Sometimes you feel like you're on the margins, and other times you don't, since sometimes it affects your life in negative ways. The margin can be a major area of creativity but it also can be an area of oppression."

Therefore, in some way for Soja it was a blessing "being in a planning department that encourages spatial thinking, like UCLA Urban Planning," something which he considered rare; offering much greater freedom, with much less weight of heavy tradition and convention in planning versus geography. Soja did not want to accept the kind of traditional notions of geography, the very core traditions, which were always shocking to him when he took courses on the history of geographic thought where nobody would talk either about space or about existing spatial thinkers such as Lefebvre. In order to really do something on space, he had to get out of geography and go to the "margins" - a school of architecture and urban planning: "Now it's beginning to occur that one can be a geographer in sociology, in political science, in economics, and be comfortable there. But that's relatively new."The UCLA Planning Department's interest in space, mainly under John Friedmann's influence as much as anything else, was a key factor in making it a comfortable place to be.

Soja was becoming increasingly well-known and could have gone to whichever university he wanted, but he had no desire to move: "there was no other place that seemed to be as attractive as UCLA." At that time he felt there was a tremendous support for what he was doing.

\section{Learning from Los Angeles}

From this time onwards Los Angeles was always on his mind and the city became a major focus for his work. But he was "not interested in learning about Los Angeles; but in learning from Los Angeles." And therefore his interest was in global urbanization. He was very concerned about China, very attentive to London, and spent some time in Amsterdam. Soja considered himself a comparative urbanist: "That's how I started, with Friedmann as well." Los Angeles was, however, his empirical laboratory:

everything is there to illustrate what is happening everywhere. Moreover, the city has changed so much that studying urban change is easier in LA than anywhere else. There are a lot of unique things about Los Angeles, making some critics argue that you can't make comparisons with LA, as LA has all of these crazy unique things. But Los Angeles also has fascinating general things happening here, that allow you to study

Singapore, or São Paulo, or Madrid from here. And that's what excites me about LA.

As an example of LA urban change, Soja mentioned that he had been writing about what he calls "off the edge cities", places like Moreno Valley far out in Riverside County. Around 18\% of the workforce had to travel more than two hours each way to work, and this was creating pathological changes: suicide, divorce, murder, child and spouse abuse. And much of it had to do with the fact that the workers were promised that the jobs would come, but this did not happen, at least not until very recently. Over the past few years, however, this area has become the most important industrial real estate in the country, with logistics firms like Amazon and so on opening up mile-long warehouses, with jobs being generated all over the place: "And so you have to watch out, for things change very rapidly in the LA region."This happened because the ports of Los Angeles are the major import-export nodes on the West Coast. Los Angeles is a distributional center to all of North America and the Pacific Rim, and vice-versa. And so there was a massive demand for logistics, warehousing and storage. 
After Postmetropolis, Soja's writings revolved around the concept of "regional urbanization," which he argued is happening all over the world ${ }^{5}$. In Soja's view, the process of regional urbanization was replacing the familiar metropolitan model of urbanization that was the previous dominant urban process: "And we must begin with a massive sea change, a metamorphosis, a paradigm shift in the urbanization process that challenges all traditional views of the city and urbanism as a way of life." Most see the metropolitan form as the end-state of urbanization. This metropolitan form was not there at the beginning of the industrial capitalist city, for example Manchester was not a metropolitan area. There were no real suburban areas. This began in the late nineteenth century and the metropolitan form of the city dominated most of the twentieth century.

Soja claimed that "this metropolitan form is characterized by a steep density gradient outward from the city center, and then a more sparsely populated area in the suburbs, with a very clear boundary existing between urban and suburban, representing two different ways of life." Usually this exists within a dominant single city, surrounded by sprawling suburbs. This "metropolitan" process is now ending, however, as a new regional urbanization process is taking its place. China is going through this now in an interesting but very different way than in the USA. So what we are seeing is the transformation of the older metropolitan structure. Suburbs are increasing in density; the boundary line between suburb and city is disappearing, and as a result we can no longer tell the difference between city and suburb. The once steep density gradient is now flattening out as the entire metropolitan region gets filled in with higher densities.

Again taking a critical perspective, Soja considered that most urban planners still believe in that metropolitan model, and one of its associated ideas: that if the heart of the city is declining, the city will die. However, that is no longer true in the polycentric regional urbanization going on today. Planners have the old model in mind when they turn to such popular strategies for the redevelopment of the city center as creating cultural cities with spectacular landmarks such as the Guggenheim Museum in Bilbao. City marketing and city branding efforts make planners believe that they, as Soja reiterated: "must go out and sell our city so we can get more tourists and that's the only way we can deal with the poor because we don't have any money for them until we can attract new investments and more tourists and even then we don't always use this for the poor, for fighting poverty." As a result of these misplaced policies, planners increasingly become entrepreneurs, spending more time attracting attention than dealing with urban problems.

This is a characteristic part of regional urbanization. The central city is likely to decline significantly, losing its current population, or becoming filled with immigrant populations, changes that will demand new policies and planning approaches. This does not mean that the city is dying though:

Detroit, for example, has lost about six hundred thousand people from its center. The inner city is now an area of enormous poverty and social problems. Yet the whole region of Detroit is booming. The outer cities of Detroit are wealthy, expanding all over the place, and so when you take measures of the whole region, Detroit is not poor, is not declining, but is actually expanding; nonetheless if you just look at the inner city it looks terrible. So that's why we need a lot more comparative studies of different experiences with regional urbanization.

Soja continued to elaborate on these ideas and also stressed that it is quite interesting to look at the differentiation of the suburbs. The suburbs used to be pretty uniform and homogeneous. The variations in suburbs were very small. Today, with regional rather than metropolitan urbanization, those variations are enormous. Some areas (this is again, regarding Los Angeles) have successfully resisted densification. The Palos Verdes area, for example, is occupied by gated community cities and so these "private governments" have been able to maintain traditional low-density suburbanization. 
Orange County represents the other end of the spectrum, once a classic suburb but now urbanized. The TV station VH1 approached me, as they wanted to do a study on punk music and they found out that punk music is most alive in Orange County. And they said"How can the suburb of LA be the world center for punk music?" Kids in Switzerland and Korea are looking to Orange County for their clothing, their lifestyle, and their music. And they interviewed me and I was saying "this is no longer a suburb. This is now a peculiar new kind of city."There are enormous pressures on youth, not because of deprivation but as they are saturated with everything they want. In a deeply politically conservative environment, this produces an urge to go overboard in rebellion, hence the Punk music flowing out of Orange County!

\section{About geographers, regional urbanization and planning for the twenty-first century}

Finally, our talk shifted to discussing the future of planning in the twenty-first century and the main challenges for geographers in planning. From Soja's standpoint, planning is going to be increasingly integrated with geography. And so what we are going to see is the emergence of a much stronger emphasis on what might be called spatial planning. This has already begun in Europe, in part due to the European Spatial Development Perspective, which he suspected was going to continue and was linked to his thoughts about regional urbanization as well.

Regional urbanization is transforming the very nature of cities everywhere, creating new linkages and, in its extended form, leading to the urbanization of the entire world. Soja believed that we are going to see the urbanization of the Amazon, of the Sahara Desert, of the Antarctic icecap and the Siberian tundra:

Every inch of the world is going to be urbanized to some degree. That doesn't mean skyscrapers. But it means that the influence of cities is going to have an effect everywhere. Already the Amazon is clearly urbanized and if you're going to study the Amazon you must see it as a complex urban network. It's more like a network than it is a thick layer of urbanism.

It is a kind of urban network that is now spreading, shaping every part of the world. Still underlying this very idea,

It's not so surprising; we're used to talking about national urban systems, so all of Portugal, all of Spain, all of the US is covered by an urban system of large cities down to small hamlets that cover the entire space.

Now a world network is being formed and it's spreading over the entire Earth surface.

Soja turned his attention to Brenner (2014) and his work Implosions/explosions: Towards a study of planetary urbanization which similarly claims that the entire Earth surface is experiencing urbanization. This is what globalization is about. What is being globalized is urbanization. It is urban industrial capitalism that is being globalized in all of its features and forms, cultural, economic and political. This is unevenly developed, as everything usually is in geography. It is more intense in some areas and very subdued in other areas but is nevertheless still there.

Wrapping up, to focus on LA as a post-modern global metropolis, there is an implicit critique of the Chicago school's approach which dominated urban geography during the twentieth century. The sprawling metropolis underlines the end of metropolitan processes, as the "line" between the suburb and the city is disappearing, revealing the polycentric regional urbanization process that is taking its place. This is one of the most important contributions of Soja's thinking for planners.

While we may not agree with Soja, what matters is his critical analysis and the challenge he poses when he argues that planners have held fast to an old model when facing the entirely new challenges of regional (not metropolitan) urbanization that is transforming cities everywhere. This explanation might begin to explain the condition of contemporary planning and some of the major challenges facing the future of planning theory and practice. 
So, in his thoughts about the future of urban planning, Soja argued that regional urbanization extending to the global scale

is going to deeply affect the nature of planning. Planning is going to have to adapt more and more to the fact that spatial planning is at its heart and its core, and we need to deal with interurban relationships, interregional relationships, global network structures going down to the local level, through the regional, again.

In his critical analysis Soja focused on the spatiality of society and on the way social relations are intertwined with space across time. Soja argued that space is socially constructed and therefore more than a background, it is essential to any understanding of human society. Soja developed spatial analysis as an alternative approach within social theory, which grasps the material and mental dimensions of spatiality, placing space at the heart of critical thinking. For planners, Soja's urban theory of the fragmented metropolis produced by the process of globalization can also be a reminder that cities are not static; they are lived spaces where we see uneven practices that intensify social and spatial polarization.

Soja's experiences also demonstrate that the context in which planners live and develop their work can be a major influence that enables (or constrains) the development of new insights. After joining the Graduate School of Architecture and Urban Planning at UCLA Soja shifted his areas of study and initiated a new critical approach, which allowed him to theorize space and elevate its role in social theory.

For Soja the purpose of our talk was to encourage geographers and urban planners to "set aside their old taboos and reservations and enthusiastically engage in these new developments not just as followers but also as intellectual leaders."

There is much more that could be said about Soja's theoretical pursuits. I hope that I have accomplished the mission I was committed to: on the one hand, to illustrate some of the ways one can be encouraged to engage with Soja's intellectual landscape. On the other, presenting a brief overview of "the perspective of a geographer, a specialist on the issues of borders and space", reflecting current debates in the field of postmodern critical studies and planning (Soja, 1996a, p. 1421), and finally, reiterating the salience of space as an on-going and important project for geographers and questioning the future of geography in planning.

\section{Notes}

1. There's a fourth book too, but with a somewhat different emphasis: Seeking Spatial Justice (University of Minnesota Press, 2010).

2. All further quotations are taken from our interview and correspondence except where indicated otherwise.

3. In Beyond Postmetropolis (Soja, 2011), a very explicit and coherent follow-up paper, Soja reflects upon some of the themes (the rediscovery of the generative power of cities, the cross-disciplinary diffusion of critical spatial perspectives, and the rising interest in regions) introduced in Postmetropolis (Soja, 2000).

\section{Acknowledgements}

I wish to express my sincere gratitude to Professor Edward Soja for providing me with an opportunity to have this conversation; by correcting and revising it he also contributed to the improvement of the final text. Nonetheless the usual disclaimer applies. By listening to the scholar we learn in ways we could not have imagined. Describing Soja's influence is like trying to define intellect; no matter what you come up with you only capture part of the story. My deepest thanks to my beloved daughter, Leonor, for her precious help in the transcription of the interview. But this interview would not have been possible without the support of Mario Vale, a 2013 Fulbright Scholar at UCLA. His recommendations and critiques contributed tremendously to the accomplishment of this task. I also express my thanks to Aidan While for believing from the beginning that this piece was interesting enough to be published in the journal Planning Theory and Practice. 


\section{Notes on contributor}

Margarida Queirós has a PhD in Human Geography from the Universidade de Lisboa (University of Lisbon). Currently she is a researcher of the Centre for Geographical Studies (http://ceg.ulisboa.pt/investigacao/investigadores/margarida-queiros/) and an Assistant Professor, at the Institute of Geography and Spatial Planning (IGOT) of the University of Lisbon, where she develops her core research at Modelling and Spatial Planning Research Group and at Assessment and Management of Environmental Hazards and Risks Research Group.

\section{References}

Brenner, N., \& Schmid, C. (2014). The 'urban age' in question. International Journal of Urban and Regional Research, 38, 731-755. Reprinted in N. Brenner (Ed.), Implosions/Explosions: Towards a study of planetary urbanization. [italics added] Berlin: Jovis, 2013, 310-337.

ESDP (1999). European Spatial Development Perspective. Towards Balanced and Sustainable Development of the Territory of the European Union. Luxembourg: Office for Official Publications of the European Communities. ISNN 92-828-7658-6 (http://europa.eu.int) Lefebvre, H. (1974). La Production de L'espace (The production of space). Paris: Éditions Anthropos. Soja, E. (1980). Socio-spatial Dialectic. Annals of the Association of American Geographers, 70(2), 207-225. Soja, E. (1989). Postmodern geographies: The reassertion of space in critical social theory. London: Verso Press. Soja, E. (1996a). Afterword. Stanford Law Review, 48, 1421-1429.

Soja, E. (1996b). Thirdspace: Journeys to Los Angeles and other real-and-imagined places. Oxford: Basil Blackwell. Soja, E. (2000). Postmetropolis: Critical studies of cities and regions. Oxford: Wiley-Blackwell. Soja, E. (2010). Seeking spatial justice. Minneapolis, MN: University of Minnesota Press.

Soja, E. (2011). Beyond postmetropolis. Urban Geography, 32, 451-469. 